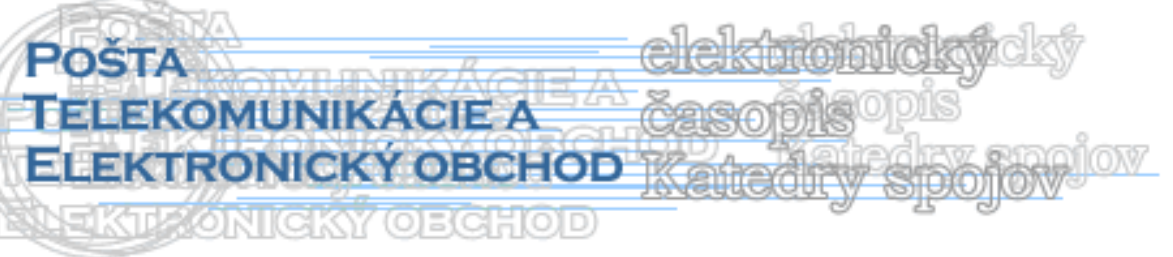

\title{
OCHRANA PRIEMYSELNÉHO VLASTNÍCTVA - CESTA DO BUDÚCNOSTI
}

\author{
Miriam Močková*
}

\section{Úvod}

V súčasnej dobe dochádza k výraznej ekonomickej nestabilite, ktorá zasahuje čoraz viac odvetví a štátov. Politici, finančníci, ekonómovia, filozofi, prognostici a d’alší, ktorí sa zamýšl'ajú nad súčasnou situáciou vo finančnej, hospodárskej ale už aj v sociálnej oblasti si uvedomujú, že dochádza k výrazným zmenám, ktoré sa nedajú vopred predvídat', prognózovat' a nikto nevie povedat' kde až kríza zájde, ktoré oblasti ešte zasiahne, a ako budú na zmenené podmienky reagovat' obyvatelia najviac postihnutých štátov.

Dá sa však predpokladat, že nasledujúce obdobie bude obdobím nebývalého urýchl'ovania vedecko-technického rozvoja, ktorý bude jedným z východísk, jedným z výziev súčasnosti ako sa čo najskôr dostat' z prehlbujúcej sa hospodárskej krízy. Vedecko-technický pokrok a následné nové kvalitné produkty a ich servis, ktoré prídu na trh, budú reakciou na uspokojovanie čoraz väčšej náročnosti spotrebitel'ov na ponúkané produkty v čase oslabenia ich kúpyschopnosti.

Po každej hospodárskej kríze príde oživenie, preto by vrcholový manažment podnikatel'ského subjektu mal v súčasnosti uvažovat' strategicky a po zorientovaní sa vo vývojových trendoch techniky, technológií ale aj záujmov trhu by mal stanovit’ hlavné smery technického a technologického vývoja a záujmov spotrebitel'ov. Aj ked' je vel'a inovačných námetov a záverov spojených s neistotou ich výsledného efektu na ekonomické výsledky a najmä v súčasnom období nesú aj vel'ké ekonomické riziko, dnešnou úlohou vrcholového manažmentu je posúdit' odvážnost' námetov a realizovatel'nost' každého inovačného projektu. V budúcnosti uspeje len ten podnikatel'ský subjekt, ktorý príde na trh s inovovaným produktom prvý alebo medzi prvými. Aj ked' si väčšie a zásadnejšie inovácie vyžadujú značné finančné prostriedky a tých je dnes nedostatok, hlavnými dôvodmi prečo by mal podnikatel'ský subjekt inovovat' sú:

- skvalitnenie výrobného procesu z dôvodu zníženia nákladov,

- uvedenie nového žiadaného výrobku,

- konkurovanie zvýšenou produktivitou,

- zvýšenie svojho podielu na trhu.

Konkurenčné prostredie medzi výrobcami v budúcom období výrazne narastie a na trhu sa presadia tie produkty, vktorých budú zabudované najnovšie, najmodernejšie technológie. Za novými nápadmi, vynálezmi, objavmi vždy stojí niekto, kto hl’adá niečo nové, premýšl'a, skúma, organizuje. Podnik bud' takýchto l'udí má, a ak nie, snaží sa nové informácie získat' zvonku. Ked’že konkurencia hl'adá rôzne cesty a zdroje získania informácií

\footnotetext{
* Ing. Miriam Močková, PhD., Katedra spojov, Fakulta prevádzky a ekonomiky dopravy a spojov, Žilinská univerzita v Žiline, Univerzitná 1, 01026 Žilina, tel.: +421415133105, fax: +421415655615 e-mail: Miriam.Mockova@fpedas.uniza.sk
} 
o výsledkoch výskumu, zavádzania nových technológií, technických riešení a výrobných spôsobov a nevynecháva možnosti získania takýchto užitočných informácií ani u svojich konkurentov, mala by mat' dnes v inovačnej politike výskumného ústavu, podniku svoje strategické miesto aj ochrana priemyselného vlastníctva.

Akademická sféra by do inovačnej oblasti mala vstupovat' širokým vedeckým, odborným a informačným potenciálom a zároveň aktívnejším využívaním svojich laboratórnych, skúšobných ale aj výrobných priestorov.

Z výročných správ Úradu priemyselného vlastníctva Slovenskej republiky (d'alej len ÚPV SR) vydaných $\mathrm{v}$ posledných rokoch vidiet', že malé množstvo prihlášok $\mathrm{z}$ oblasti priemyselného vlastníctva podaných podnikatel'skými subjektmi pôsobiacimi v Slovenskej republike ukazuje, že mnohí ešte nevedia, že ich technické riešenie, vynález, dizajn alebo aj názov ich firmy môže cudzia osoba l'ahko zneužit' a beztrestne sa na ich úkor obohatit'.

Úrad priemyselného vlastníctva SR so sídlom v Banskej Bystrici vykonáva ústrednú štátnu správu voblasti ochrany vynálezu, úžitkového vzoru, dizajnu, topografie polovodičového výrobku, ochrannej známky, označenia pôvodu výrobku a zemepisného označenia výrobku, vedie tiež fond patentovej literatúry a zabezpečuje výmenu a sprístupňovanie informácií v oblasti priemyselných práv.

\section{Akým spôsobom je možné chránit’ priemyselné vlastníctvo?}

Vynález ako nové a tvorivé riešenie technického problému alebo aj d'alšie vylepšenie známeho výrobku, poskytuje po získaní patentu, vlastníkovi vynálezu výlučné právo zakázat' alebo zabránit' iným osobám bez jeho predchádzajúceho súhlasu vyrábat', používat', ponúkat' na predaj, predávat' alebo dovážat' výrobok, ktorý je založený na patentovom vynáleze. Z uvedeného vidiet', že patent je pre podnikatel'ský subjekt významný obchodný nástroj, ktorý mu poskytuje exkluzivitu na výrobok a tým aj možnost' vybudovat' si silnú pozíciu na trhu alebo získanie finančných prostriedkov z licencií alebo predaja patentu. Patenty na vynálezy udel’uje už spomínaný ÚPV SR.

Treba si však uvedomit’ rozdiel medzi „vynálezom“ a „inováciou“. Vynález sa týka technického riešenia, ktoré sa musí dat' prakticky zrealizovat' a využit'. Inovácia je v súvislosti s vynálezom jeho pretransformovanie na obchodovatel'ný výrobok.

Dizajn vytvára pridanú hodnotu výrobku. Zmenou dizajnu sa pre spotrebitel'ov môže stat' výrobok atraktívnejším a pôsobivejším. Aj malé úpravy dizajnu niektorých výrobkov môžu vyhovovat' určitej sociálnej alebo vekovej skupine l'udí a dokonca môžu byt' hlavným kritériom jeho predajnosti a zároveň odlíšia výrobok od výrobku konkurencie.

Ochrana nového originálneho dizajnu sa robí jeho zápisom na ÚPV SR, ktorý dáva jeho majitel'ovi výlučné právo bránit' tretím osobám kopírovat' alebo napodobňovat' zapísaný dizajn a tým posilňuje majitel'ovi konkurenčnú pozíciu na trhu. Chránený dizajn môže byt' tiež predmetom licencie a predaja.

Schopnost' odlíšenia podnikatel'ských subjektov, ich výrobkov a služieb od konkurencie zabezpečujú ochranné známky, ktoré zároveň prispievajú k zvyšovaniu imidžu a reputácie podnikatel'ského subjektu v očiach zákazníkov. Za ochrannú známku sa považujú slová, písmená, číslice, kresby rôznych tvarov a ich vzájomné kombinácie rozlíšené i farebne, ktoré sú použité na odlíšenie ich tovarov a služieb.

Spotrebitelia spájajú ochrannú známku s kvalitou, ktorá je s ňou spojená a sú neraz ochotní zaplatit’ za výrobok so známou ochrannou známkou viac, lebo ju uznávajú a napíña ich očakávania. Aj ked' si toto väčšina podnikatel'ských subjektov uvedomuje, nie všetci si uvedomujú dôležitost' ochrany ochrannej známky prostredníctvom registrácie na ÚPV SR.

Mnohí podnikatelia si myslia, že registráciou obchodného mena v obchodnom registri sa toto obchodné meno automaticky chráni ako ich ochranná známka, čo nie je pravda. 
Obchodným menom sa rozumie názov, pod ktorým podnikatel' vykonáva právne úkony pri svojej podnikatel'skej činnosti a ktorým sa zároveň odlišuje od iných podnikatel'ov. Ochranná známka je označenie, ktoré spôsobuje rozlíšit' tovary alebo služby jedného podnikatel'a od iného.

Starostlivo vytvorená, registrovaná ochranná známka je cenným obchodným aktívom podnikatel'ského subjektu, navyše môže byt' predmetom licenčnej zmluvy a tým aj zdrojom d'alšieho zisku.

Technické riešenia, ktoré sú nové, presahujú rámec prostej odbornej schopnosti a sú priemyselne využitel'né sa dajú chránit' úžitkovými vzormi. Úžitkové vzory, ktoré zapisuje do registra ÚPV SR majú vol'nejšie podmienky zápisu, nakol'ko u nich nie je povinná podmienka vynálezcovskej činnosti.

Podnikatel'ské subjekty zabudovávajú do svojich nových výrobkov stále inteligentnejšie prvky polovodičových a mikroelektronických častí určených na plnenie elektronickej funkcie výrobkov, čím rastie nielen ich výkonnost' a kvalita, ale tieto ich inovované, modernejšie výrobky majú aj vyššiu úžitkovú hodnotu. Aj tieto časti elektroniky topografie polovodičových výrobkov sa dajú chránit’. Ich ochrana je možná vtedy ak je topografia „výsledkom tvorivej duševnej činnosti pôvodcu, ktorá nie je vodvetví polovodičových výrobkov bežná.“ [6] Majitel’ topografie má okrem iného výlučné právo zakázat' inému vyrábat' polovodičový výrobok ak obsahuje topografiu, ktorú ÚPV SR zapísal na jeho meno v registri topografií.

Zákonom sú upravené aj podmienky získania práva na ochranu označenia pôvodu výrobku alebo zemepisného označenia výrobku, ktoré však podnikatel'ské subjekty zatial' skoro ani nevyužívajú.

Označením pôvodu výrobku sa rozumie názov určitého miesta, oblasti alebo krajiny „používaný na označenie výrobku pochádzajúceho z tohto miesta, oblasti alebo krajiny, ak kvalita alebo vlastnosti tohto výrobku sú výlučne alebo podstatne dané zemepisným prostredím s jeho charakteristickými prírodnými a l'udskými faktormi a výroba, spracovanie a príprava tohto výrobku sa uskutočňuje výlučne vo vymedzenom mieste, oblasti alebo krajine“ [7].

Zemepisným označením výrobku sa rozumie názov určitého miesta, oblasti alebo krajiny ,používaný na označenie výrobku pochádzajúceho z tohto miesta, oblasti alebo krajiny, ak má tento výrobok špecifickú kvalitu, povest' alebo charakteristické vlastnosti, ktoré môžu byt' pripísané tomuto miestu, oblasti alebo krajine a výroba, spracovanie alebo príprava tohto výrobku sa uskutočňuje vo vymedzenom zemepisnom mieste, oblasti alebo krajine“ [7].

V oblasti registrácie označení pôvodu výrobkov a zemepisných označení došlo podl’a výročnej správy Úradu priemyselného vlastníctva SR z roku 2008 k určitému zvýšeniu povedomia najmä v odborných kruhoch pracujúcich $\mathrm{v}$ pol'nohospodárstve o čom svedčí aj tá skutočnost', že v januári 2008 bol „Skalický trdelník“ prvým slovenským zemepisným označením zapísaným do registra Európskej komisie.

\section{Záver}

Vzhl'adom k tomu, že systém ochrany priemyselného vlastníctva je vysoko odborný a dost' zložitý, môže manažment podnikatel'ského subjektu využit' odborné poradenstvo od patentového zástupcu, ktorý preň môže spísat' aj listiny potrebné pre právne úkony v oblasti priemyselných práv, ale môže aj priamo zastupovat' podnikatel'ský subjekt v konaní pred ÚPV SR. Patentový zástupca je členom Slovenskej komory patentových zástupcov a pri výkone svojej činnosti a poskytovaní služieb je povinný chránit’ práva a oprávnené záujmy podnikatel'ského subjektu, ktorý zastupuje. 
Výlučné práva, ktoré vyplývajú z udelenia patentu, zápisu dizajnu či zaregistrovania ochrannej známky zabezpečujú nielen ich ochranu v rizikovom a dynamickom prostredí obchodu ale môžu byt' rozhodujúce pre prosperitu inovačných podnikatel'ských subjektov.

\section{Literatúra}

[1] Zákon č. 575/2001 Z. z. o organizácii činnosti vlády a organizácii ústrednej štátnej správy v znení neskorších predpisov.

[2] Zákon č. 435/2001 Z. z. o patentoch, dodatkových ochranných osvedčeniach a o zmene a doplnení niektorých zákonov (patentový zákon) v znení neskorších predpisov.

[3] Zákon č. 444/2002 Z. z. o dizajnoch v znení neskorších predpisov.

[4] Zákon č. 55/1997 Z. z. o ochranných známkach v znení neskorších predpisov.

[5] Zákon č. 517/2007 Z. z. o úžitkových vzoroch v znení neskorších predpisov.

[6] Zákona č. 146/2000 Z. z. o ochrane topografií polovodičových výrobkov

[7] Zákon č. 469/2003 Z. z. o označeniach pôvodu výrobkov a zemepisných označeniach výrobkov v znení neskorších predpisov.

[8] Zákon č. 344/2004 Z. z. o patentových zástupcoch, o zmene zákona 444/2002 Z. z. o dizajnoch a zákona č. 55/1997 Z. z. o ochranných známkach v znení zákona č. 517/2007 Z. z. a zákona č. 14/2004 Z. z.

[9] Výročná správa Úradu priemyselného vlastníctva Slovenskej republiky 2004, ISBN 8088994-41-1

[10]Výročná správa Úradu priemyselného vlastníctva Slovenskej republiky 2005, ISBN 8088994-51-9

[11] Výročná správa Úradu priemyselného vlastníctva Slovenskej republiky 2006, ISBN 97880-88994-55-8

[12] Výročná správa Úradu priemyselného vlastníctva Slovenskej republiky 2007, ISBN 97880-88994-58-9

[13] Výročná správa Úradu priemyselného vlastníctva Slovenskej republiky 2008, ISBN 97880-889994-61-9

[14]Vytvorme si ochrannú známku, Edícia Duševné vlastníctvo a podnikanie č. 1., WIPO Publikácia No. 900(SK), 2003, ÚPV SR, ISBN 92-805-1413-X

[15]Prít’ažlivý vzhl’ad, Edícia Duševné vlastníctvo a podnikanie č. 2., WIPO Publikácia No 498(SK), 2003, ÚPV SR, ISBN 92-805-1414-8

[16]Vynaliezanie budúcnosti, Edícia Duševné vlastníctvo a podnikanie č. 3., WIPO Publikácia č. 917(SK), 2006, ÚPV SR, ISBN 978-92-805-1635-7

[17]Duševné vlastníctvo 4/2008, Revue pre teóriu a prax $\mathrm{v}$ oblasti duševného vlastnítva, ÚPV SR, ISSN 1335-2881

\section{Grantová podpora}

Príspevok je publikovaný v rámci projektu VEGA 1/0468/08 - Inovačná stratégia v sektore služieb.

Príspevok je publikovaný v rámci projektu APVV-0230-07 - Regionálne dimenzie poznatkovej ekonomiky. 